\title{
Incidence of epilepsy in multiple sclerosis patients
}

\author{
Iris Zavoreo $^{1}$, Miljenka Jelena Jurašić ${ }^{1}$, Lucija Zadro Matovina ${ }^{1}$, Vanja Bašić Kes ${ }^{1}$ \\ ${ }^{1}$ University Department of Neurology, UHC Sestre milosrdnice, Zagreb, Croatia
}

OPEN ACCESS

Correspondence: Iris Zavoreo iris_zavoreo@yahoo.com orcid.org/0000-0001-9358-1665

This article was submitted to RAD CASA - Medical Sciences as the original article

Conflict of Interest Statement: The authors declare that the research was conducted in the absence of any commercial or financial relationships that could be construed as a potential conflict of interest.

Received: 28 April 2021 Accepted: 5 May 2021 Published: 15 June 2021

Citation:

Zavoreo I, Jurašić M J, Zadro Matovina $L$, Bašić Kes V. Incidence of epilepsy in multiple sclerosis patients: RAD CASA - Medical Sciences. $547=54-55$ (2021): 20-23 DOI: https://dx.doi.org/10.21857/ m16wjcexo9

Copyright (C) 2021 Zavoreo I, Jurašić M J, Zadro Matovina L, Bašić Kes V. This is an open-access article distributed under the terms of the Creative Commons Attribution License (CC BY). The use, distribution or reproduction in other forums is permitted, provided the original author(s) and the copyright owners(s) are credited and that the original publication in this journal is cited, in accordance whit accepted is cited, in accordance whit accepted
adacemic practice. No use, distribution or reproduction is permitted which does not comply with these terms.

\section{ABSTRACT:}

Previously epilepsy was recognized as part of the multiple sclerosis (MS) disease spectrum and treatment with antiepileptic drugs was part of symptomatic MS therapy. These comorbidities in the same patient despite being well known still has not been fully understood.

The aim of this study was to evaluate incidence and clinical presentation of epilesy in population of our MS patients. We included in our study 200 patients evaluated in our MS center, 145 females and 55 males.

Results: there was no statistically significant difference in mean age, disease duration, EDSS score between MS with and MS without epilepsy groups, no differences in clinical presentation of seizures according to the previous immunomodulatory treatment $(\mathrm{p}>0,05)$. We found EEG abnormalities in $50 \%$ of patients with MS and seizures, in 35\% MS patients without seizures, pooled incidence of epilepsy in 3.5\% with peak incidence between 4 and 7 years after the onset of multiple sclerosis. There was difference of seizure incidence according to clinical course of MS.

The treatment of epilepsy in patients with multiple sclerosis does not requires specific protocols than the general epileptic population, but requires individualized approach in order to achieve the best treatment for both diseases.

\section{KEYWORDS: epilepsy, multiple sclerosis, treatment}

\section{SAŽETAK:}

INCIDENCIJA EPILEPSIJE U BOLESNIKA S MULTIPLOM SKLEROZOM

Incidencija epilepsije u bolesnika s multiplom sklerozom Prije je epilepsija bila prepoznata kao dio spektra multiple skleroze (MS) kao bolesti, a liječenje antiepileptičkim lijekovima bilo je dio simptomatske MS terapije. Interakcije ove dvije bolesti kada se jave u istog pacijenta još uvijek nisu dobro istražene, iako su dobro poznate same za sebe.

Cilj ove studije bio je procijeniti učestalost i kliničku prezentaciju epilesije u populaciji naših MS bolesnika. U našu smo studiju uključili 200 pacijenata procijenjenih u našem MS centru, 145 žena i 55 muškaraca.

Rezultati: nije bilo statistički značajne razlike u prosječnoj životnoj dobi, trajanju bolesti, EDSS zbroju između MS s i MS bez epilepsijskih skupina, nije bilo razlike u kliničkoj prezentaciji napadaja prema prethodnom imunomodulatornom liječenju ( $\mathrm{p}>0,05)$. Otkrili smo EEG abnormalnosti u 50\% bolesnika s MS-om i napadajima, u 35\% bolesnika s MS-om bez napadaja, ukupnu pojavnost epilepsije u $3,5 \%$ s najvećom učestalošću između 4 i 7 godina nakon početka multiple skleroze. Postojala je razlika u učestalosti napadaja prema kliničkom tijeku MS-a.

Liječenje epilepsije u bolesnika s multiplom sklerozom ne zahtijeva posebne protokole od opće epileptične populacije, ali zahtijeva individualizirani pristup kako bi se postiglo najbolje liječenje za obje bolesti.

KLJUČNE RIJEČI: epilepsija, multipla skleroza, terapija 


\section{INTRODUCTION:}

Multiple sclerosis (MS) is autoimmune disease of the central nervous system. Previously epilepsy was recognized as part of the MS disease spectrum and treatment with antiepileptic drugs was part of symptomatic MS therapy. These comorbidities in the same patient despite being well known, still has not been fully understood. Seizures appear in only a minority of patients with MS, but they can have serious consequences. The treatment of MS can be epileptogenic, and antiepileptic treatment can conversely worsen the symptoms of MS, therefore further investigation are needed. ${ }^{1,2}$

The risk of epilepsy in patients with multiple sclerosis is 3 to 6 times higher than the healthy population (general population ranges from 0.27 to $1.7 \% .1$, in patients with multiple sclerosis (MS) average of $2.3 \%$ (range $0.5-10.8 \%$ ). It is more common in young age with peak incidence between 4 and 7 years after the onset of multiple sclerosis. It is important to consider that patients with MS during the course of the disease may show clinical symptoms such as paroxysmal epileptic-like spasms, dizziness, diplopia, and more, to differentiate the disease seizure in order to establish the correct clinical diagnosis and therapy. ${ }^{3,4}$

The aim of this study was to evaluate incidence and clinical presentation of epilepsy in population of our MS patients.

\section{PATIENTS AND METHOdS:}

We included in our study 200 patients evaluated in our MS center, University Department of Neurology, UHC Sestre milosrdnice in Zagreb during last year. MS diagnose was established according to revised Mc Donald criteria. ${ }^{5}$ Diagnose of epilepsy was established according to criteria of the International League Against Epilepsy (ILAE). ${ }^{6} \mathrm{MS}$ patients were divided in group relapse remitted MS (RRMS) and primary progressive MS (PPMS) and incidence of epileptic seizures was evaluated in these two populations. We evaluated age, gender, disease duration, immunomodulatory therapy and EDSS value. For statistical evaluation, we used Statistica software (TIBCO Software, Inc. Kalifornija, SAD), ANOVA test for demographic data and $\chi^{2}$ test for parametric data, statistical significance was $\mathrm{p}<0,05$.

\begin{tabular}{|l|l|l|}
\hline & MS PATIENTS WITH EPILEPSY & MS PATIENTS WITHOUT EPILEPSY \\
\hline Females & $6(3 \%)$ & $139(69.5 \%)$ \\
\hline Males & $1(0.5 \%)$ & $54(27 \%)$ \\
\hline $\begin{array}{l}\text { Mean age } \\
\text { (years } \pm \text { standard deviation) }\end{array}$ & \multicolumn{2}{|c|}{$36 \pm 16$} \\
\hline MS disease duration (years) & $5(2.5 \%)$ & $155(77.5 \%)$ \\
\hline RRMS & $2(1 \%)$ & $38(19 \%)$ \\
\hline PPMS & $5(2.5 \%)$ & 0 \\
\hline Seizure in relapse of MS & $3(1.5 \%)$ & 0 \\
\hline $\begin{array}{l}\text { Immunomodulatory therapy before } \\
\text { seizure }\end{array}$ & $4(2 \%)$ & $160(80 \%)$ \\
\hline $\begin{array}{l}\text { No Immunomodulatory therapy before } \\
\text { seizure }\end{array}$ & \multicolumn{2}{|c|}{$38(19 \%)$} \\
\hline EDSS 0-4 & \multicolumn{2}{|c|}{$2(1 \%)$} \\
\hline EDSS 4-6 & \multicolumn{2}{|c|}{80} \\
\hline EDSS $>7$ & & \\
\hline
\end{tabular}

*data were presented as absolute numbers and percentages 


\section{RESULTS}

We included in our study 200 patients, 145 females and 55 males, there was no statistically significant difference in mean age, disease duration and EDSS score between MS with and MS without epilepsy groups ( $p>0,05)$, therefore pooled data are presented for these parameters. In our study, we found 6 females and 1 male patient with MS and seizures; while most of the patients were seizure free ( 139 females and 54 males). When evaluated seizure incidence according to MS clinical presentation there was 5 patients with RRMS and 2 patients with PPMS $(p=0.047) ; 5$ patients had seizures as presentation of MS relapse $(\mathrm{p}=0.048)$. When evaluating seizure types 3 were generalized seizures and 4 were focal according to ILAE classification, there was no differences in clinical presentation of seizures according to the clinical course of MS (RRMS; PPMS). There was no difference in seizure presentation according to previous immunomodulatory therapy $(p>0.05)$. When we correlate EDSS values between the groups we did not found statistically significant differences between the MS with epilepsy and without epilepsy patients ( $\mathrm{p}>0.05$ ). Brain magnetic resonance imaging (MRI) findings have shown diffuse lesions, including as well cortical, iuxtacortical lesions and different grades of atrophy but there was no statistically significant differences according to the MS population without seizures $(p>0,05)$,. We found EEG abnormalities in $50 \%$ of patients with MS and seizures, in 35\% MS patients without seizures.

\section{DiscusSION}

The risk of epilepsy in patients with multiple sclerosis is 3 to 6 times higher than the healthy population (general population ranges from 0.27 to $1.7 \% .1$, in patients with multiple sclerosis (MS) average of $2.3 \%$ (range $0.5-10.8 \%$ ). In our study, we found pooled incidence of $3.5 \%, 3 \%$ in females and $0.5 \%$ in males. ${ }^{1,4}$

It is more common in young age with peak incidence between 4 and 7 years after the onset of multiple sclerosis, in our study at the time of seizure appearance mean duration of the MS was 8 years. ${ }^{1,4}$

It is more prevalent in the female sex, the frequency of seizures seems to be related to the number of exacerbations of multiple sclerosis and the seat of injury especially when present in the cortical or iuxtacorticali (substrate consists of areas of inflammation and demyelination in the cortex and white matter justacorticale with reactive gliosis, edema and alterations of enzyme ATP $\mathrm{Na}-\mathrm{K}$ dependent). In cases with varying degrees of atrophy it is assumed that the alteration of sodium channels may be a common pathogenetic element in the same patient from the onset of epilepsy and multiple sclerosis, especially when epilepsy precedes the onset of MS. In our study most of the patients were females, most of the seizures appeared in relapse of MS, MRI findings have shown diffuse lesions, including as well cortical, iuxtacor- tical lesions and different grades of atrophy but there was no statistically significant differences according to the MS population without seizures. ${ }^{7-9}$

Seizures are included in the spectrum of multiple sclerosis symptoms and they may arise in the course of relapse or always be present. Crises can be partial or generalized, primary or secondary, with the same prevalence of epileptic general population. Partial seizures with or without secondary generalization are the most frequent type. Among the partial seizures, focal seizures are twice as frequent complex partial unlike the general population in which this ratio is reversed. In our study there was no statistically significant difference in number of generalized and focal seizures, there was no differences in clinical presentation of seizures according to the clinical course of MS (RRMS; PPMS). ${ }^{10-12}$

It is important to consider that patients with MS during the course of the disease may show clinical symptoms such as paroxysmal epileptic-like spasms, dizziness, diplopia, and more, to differentiate the disease seizure in order to establish the correct clinical diagnosis and therapy. ${ }^{11}$

Seizures can also be a rare side effect of therapies for multiple sclerosis in particular glatiramer acetate, fampridine, cannabis and derivatives or even more rarely with beta interferon, probably for a lowering of the seizure threshold. In our study, we did not found impact of immunomodulatory or other MS therapy on epileptic seizures. ${ }^{13}$

EEG abnormalities are present in approximately $60 \%$ of patients with multiple sclerosis and are generally in relation to the site of injury or over the stage of the disease and the particular type of course The relationship between the EEG and neuroradiological finding to date have not yet been clearly defined. Presumably in the early stages of disease flare edema present level of demyelinating lesions that may have epileptogenic effects would be reduced with steroid therapy. Patients with epilepsy and MS have cortical inflammatory lesions that would explain focal onset seizures during relapses or as debut of MS. However, some patients build up numerous epileptogenic processes, developing seizures away from relapses, perpetuating neurodegeneration and cognitive impairment. These patients should be the center for new treatment strategies targeting the detention of the epileptogenic progression. We found EEG abnormalities in 50\% of patients with MS and seizures, but also in $35 \%$ of MS patients without seizures, it is according to previously mentioned facts. ${ }^{14}$

Seizure control is essential for people with epilepsy not only because of general health, but also because of their psychosocial functioning as well as mortality rate reduction, including sudden unexpected death (SUDEP). ${ }^{13}$

The treatment of epileptic disease in patients with multiple sclerosis does not requires specific protocols than the general epileptic population. We should think only about the comedication for both disease and possible interactions and side effects, for example- use of phenobarbital could accentuate cognitive 
deficits so it is recommended not to use it. When used, carbamazepine, lamotrigine or gabapentin could induce increased fatigue, disorders of balance, the cognitive slowing, the onset or aggravation of their symptoms of MS such disorders cerebellar, pyramidal signs, micturition disorders. The new AEDs are good therapeutic option for which the antiepileptic therapy in patients with multiple sclerosis. Number of patients in our study was too low for statistical evaluation of AED and their impact on disease course as well as patient everyday functioning, for these purposes further studies should be performed as follow up studies with higher number of patients. ${ }^{13,14}$

\section{REFERENCES:}

1. Vincent A, Crino PB. Systemic and neurologic autoimmune disorders associated with seizures or epilepsy. Epilepsia. 2011; 52:12-7. doi: 10.1111/j.1528-1167.2011.03030.x

2. Horakova D, Kalincik T, Dusankova JB, Dolezal O. Clinical correlates of grey matter pathology in multiple sclerosis. BMC Neurol. 2012; 12:10. doi: 10.1186/1471-2377-12-10

3. Koch M, Uyttenboogaart M, Polman S, De Keyser J. Seizures in multiple sclerosis. Epilepsia. 2008; 49:948-53. doi: 10.1111/j.1528-1167.2008.01565.x

4. Uribe-San-Martin R, Ciampi-Diaz E, Suarez-Hernandez F, Vásquez-Torres M, Godoy-Fernández J, Cárcamo-Rodríguez C. Prevalence of epilepsy in a cohort of patients with multiple sclerosis. Seizure. 2014; 23:81-3. doi: 10.1016/j. seizure.2013.09.008

5. Thompson AJ, Banwell BL, Barkhof F, Carroll WM, Coetzee T, Comi G.et al. Diagnosis of multiple sclerosis: 2017 revisions of the McDonald criteria. Lancet Neurol. 2018; 17:162-73. doi: 10.1016/S1474-4422(17)30470-2

6. Scheffer IE, Berkovic S, Capovilla G, Connolly MB, French J, Guilhoto L, et al. ILAE classification of epilepsies: position paper on the ILAE commission for classification and terminology. Epilepsia. 2017; 58:512-21.doi: 10.1111/ epi.13709

7. Geurts JJ, Bö L, Pouwels PJ, Castelijns JA, Polman CH, Barkhof F. Cortical lesions in multiple sclerosis: combined post-mortem MR imaging and histopathology. Am J Neuroradiol. 2005; 26:572-7.

8. Calabrese M, Stefano N, Atzori M, Bernardi V, Mattisi I, Barachino L, et al. Extensive cortical inflammation is associated with epilepsy in multiple sclerosis. J Neurol. 2008; 255:581-6. doi: 10.1007/s00415-008-0752-7
9. Martínez-Lapiscina EH, Ayuso T, Lacruz F, Gurtubay IG, Soriano G, Otano M, et al. Cortico-juxtacortical involvement increases risk of epileptic seizures in multiple sclerosis. Acta Neurol Scand. 2013; 128:24-31. doi: 10.1111/ ane. 12064

10. Burman J, Zelano J. Epilepsy in multiple sclerosis: a nationwide population-based register study. Neurology. 2017; 89:2462-8. doi: 10.1212/WNL.0000000000004740.

11. Gasparini S, Ferlazzo E, Ascoli M, Sueri C, Cianci V, Russo C, et al. Risk factors for unprovoked epileptic seizures in multiple sclerosis. A systematic review and meta-analysis. Neurol Sci. (2017) 38:399-406. doi: 10.1007/s10072-0162803-7

12. Benjaminsen E,Myhr KM, Alstadhaug KB. The prevalence and characteristics of epilepsy in patients with multiple sclerosis in Norland county, Norway. Seizure. 2017; 52:131-5. doi: 10.1016/j.seizure.2017.09.022

13. Dagiasi I, Vall V, Kumlien E, Burman J, Zelano J. Treatment of epilepsy in multiple sclerosis. Seizure. 2018; 58:47-51. doi: 10.1016/j.seizure.2018.04.001

14. Durmus H, Kurtuncu M, Tuzun E, Pehlivan M, AkmanDemir G, Yapici Z, et al. Comparative clinical characteristics of early and adultonset MS patients with seizures. Acta Neurol Belg. 2013; 113:421-6. doi: 10.1007/s13760-0130210-x 